\title{
Discrimination and the Private Law in Canada: Reflections on Spence v. BMO Trust Co.
}

\section{Jane Thomson*}

Discrimination has long been identified as detrimental to the basic functioning of multicultural countries like Canada. While governments have adopted constitutional law and passed human rights legislation to combat and control discrimination, these laws are inapplicable to a significant portion of Canadian law. Areas of private law, such as wills and trusts are therefore more vulnerable to use by individuals seeking to perpetuate discrimination.

The main way that courts in Canada have dealt with this issue is through the use of the doctrine of public policy. As early as the $19^{\text {th }}$ century, private law provisions viewed as restraining another's freedom of religion or perpetuating discrimination on grounds such as race, ethnicity, or sexual orientation have been found contrary to public policy by Canadian courts and voided accordingly.

While the uniquely Canadian jurisprudence in this area continues to evolve, until quite recently, its trajectory appeared to be one of expansion. However, the latest appellate level decision in this area, Spence v. BMO Trust Co., appears to have changed the course of this jurisprudence. In Spence, the Ontario Court of Appeal found that certain testamentary clauses, no matter how discriminatory in nature, can never be subject to a public policy review.

This article argues that while the result of Spence was likely correct on its particular facts, the reasoning of that decision goes too far in its attempt to limit the doctrine's applicability with respect to discrimination in the private law. Parts of the decision in Spence ignore the key message of past decisions in this area concerning the danger of uncensored discrimination in Canadian society.

While reasonable people may disagree on the outcome of any given public policy inquiry, a point that should attract consensus is that the private law should never be an unexamined and impenetrable shelter for discrimination. However, Spence effectively creates an area of the private law immune to legal scrutiny by precluding the use of the common law doctrine that has been used to directly confront and censure discrimination in Canadian private law.

Il est reconnu depuis longtemps que la discrimination nuit au fonctionnement de base des pays multiculturels comme le Canada. Bien que les gouvernements aient adopté des principes de droit constitutionnel et des lois sur les droits de la personne afin d'exercer un contrôle sur la discrimination et de la combattre, ces lois sont inapplicables à une partie importante du droit canadien. En conséquence, certains aspects du droit privé, comme ce qui touche les testaments et les fiducies, sont davantage susceptibles d'être utilisés par des personnes qui cherchent à perpétuer la discrimination.

Au cours des années, les tribunaux canadiens ont examiné cette question principalement sous l'angle de la doctrine d'intérêt public. Dès le XIX siècle, ils ont jugé en effet que

* Associate Professor, University of New Brunswick's Faculty of Law. The author wishes to acknowledge the excellent research assistance of UNB law students Mark Heighton and Erik Arsenault. 
certaines règles du droit privé qui restreignaient la liberté de religion ou perpétuaient la discrimination fondée sur des motifs comme la race, l'ethnicité ou l'orientation sexuelle allaient à l'encontre de l'intérêt public, et ils ont déclaré ces règles inopérantes.

Bien que la jurisprudence spécifique au Canada dans ce domaine continue d'évoluer, sa trajectoire semblait, jusqu'à récemment, en être une d'expansion. Cependant, par suite de la plus récente décision rendue par une juridiction d'appel dans ce domaine, Spence c. BMO Trust Co., cette trajectoire semble avoir été modifiée. En effet, dans l'arrêt Spence, la Cour d'appel de l'Ontario a jugé que certaines clauses testamentaires ne peuvent en aucun cas faire l'objet d'une révision fondée sur l'intérêt public, si discriminatoires soientelles.

Dans cet article, l'auteure soutient que, même si le résultat obtenu dans l'arrêt Spence était probablement correct au vu des faits particuliers de l'affaire, le raisonnement qui sous-tend la décision va trop loin dans la mesure où il a pour effet de restreindre l'applicabilité de la doctrine en ce qui a trait à la discrimination en droit privé. Certaines parties de l'arrêt Spence ignorent le message clé des décisions antérieures concernant le danger que présente la discrimination non censurée dans la société canadienne.

S'il est possible que des personnes raisonnables n'acceptent pas le résultat d'une enquête menée dans l'intérêt public, l'idée que le droit privé ne saurait en aucun cas constituer un abri impénétrable pour ceux qui se livrent à des pratiques discriminatoires devrait faire consensus. Cependant, l'arrêt Spence a pour effet de permettre qu'un aspect du droit privé échappe à un examen juridique en empêchant l'application de la doctrine de common law qui a été utilisée pour combattre et censurer directement la discrimination en droit privé canadien.

\section{INTRODUCTION}

Discrimination has long been identified as detrimental to democratic societies and a foil to multicultural countries like Canada, where people of various religions, races, ideologies, sexual orientation and genders must live together. While the Canadian government has responded to this reality through the introduction and passage of legislation and constitutional law that regulates discrimination in a multitude of contexts, there remain portions of our legal system to which such laws do not apply. These include areas like private wills, trusts, and contracts formed between individuals. In these areas, where neither the Charter nor any provision of a provincial or federal human rights code applies, individuals can legally use the private law to perpetuate discrimination. Writing about this in a slightly different context, Justice Bora Laskin described this phenomenon as the use of a well-established common law rule by private individuals "to suppress a lawful activity supported both by legislation and by a well-understood legislative policy."1

One way that courts in Canada have dealt with this issue is through the use of the doctrine of public policy to review and sometimes void discriminatory clauses in wills, private trusts and restrictive covenants. Public policy, a principle of the common law that dates back to at least the $15^{\text {th }}$ century, has been applied by courts to override a variety of otherwise valid common law rules when the operation of those rules would result in a harm to the "public good". 2 While Canadian courts have voided discriminatory provisions in the private law as early as the $19^{\text {th }}$ century ${ }^{3}$, the jurisprudence in this area is

Harrison v Carswell, [1976] 2 SCR 200, 1975 CarswellMan 58 at 202.

See Egerton v Earl Brownlow, [1853] 4 HL Cas 1, 10 ER 359 at 196 [Egerton].

Kimpton v CPR (1888) MLR 4 SC 338 [Kimpton]. 
by no means settled. For example, not all acknowledged instances of discrimination in a will or a testamentary trust have been found to be contrary to public policy when subjected to a review under the doctrine. This has remained the case, even after a clear shift in societal tolerance for racial or religious discrimination took place in Canada following the passage of provincial and federal human rights legislation and the adoption of the Charter of Rights and Freedoms. ${ }^{4}$

The precise determination of what level of discrimination is compatible with the functioning of Canadian society remains a case-by-case evaluation, just as it is in public law (albeit without the latter's formal tests). However, not since the 1930s has a Canadian court found that a public policy inquiry was totally unavailable to a party seeking to challenge a discriminatory provision in a will. ${ }^{5}$ This changed in 2016 with the release of Spence v BMO Trust Co. ${ }^{6}$ where the Ontario Court of Appeal drew a categorical line in the sand, declaring that the doctrine can never be applied to certain provisions in private wills no matter how discriminatory they might be.

This article argues that while the result of Spence was likely correct on its particular facts, the reasoning of that decision goes too far in its attempt to limit the doctrine's applicability in general with respect to discrimination in the private law. After an examination of the doctrine's history, both in general and with respect to this particular area of jurisprudence in Canada, it becomes clear that this finding in Spence runs directly contrary to the basic reasoning repeatedly used to justify applications of public policy to discrimination in the private law in Canada. While the history of the doctrine clearly demonstrates that similar efforts to quash or contain it by higher levels of court have categorically failed, the immediate implications of Spence are yet to be felt. What is clear, however, is that the ruling based on the hypothetical scenario in Spence unnecessarily erects barriers that, at least in the short term, may impede those seeking to prevent discrimination within the private law. More disturbingly it appears to send the message that a will or a trust can be effectively used to perpetuate discrimination, and even involve a court of law in this endeavor. Arguably this reasoning is at odds with those basic principles such as equality, tolerance and dignity, upon which the Canadian system of justice rests. Reasonable people will have differing views on how discrimination in the private law context should be addressed. Likely, they will also disagree on what competing rights should be balanced against one another when evaluating a particular instance of discrimination. ${ }^{7}$ Nevertheless, a basic argument that should attract consensus is that the private law must not become an unexamined and impenetrable tool to perpetuate discrimination. However, when the applicability of public policy review is precluded from a discriminatory use of the private law, this is precisely what happens.

Part II of this article provides the history, facts and ruling in Spence. Part III of this paper provides a necessary overview of the doctrine's history and its application to discrimination in the uniquely Canadian context. Part IV of this paper revisits Justice Cronk's ruling in Spence and explains how Justice Cronk's majority decision in Spence conflates two very different scenarios involving the private law and the perpetuation of discrimination. In it she applies the same reasoning to both the actual facts of Spence and to a hypothetical scenario, even though the hypothetical differs fundamentally in nature from the case's facts. This article concludes with some thoughts on the repercussions of this decision with respect to discrimination in the area of private wills and testamentary trusts.

\footnotetext{
Part I of the Constitution Act, 1982, being Schedule B to the Canada Act 1982 (UK), 1982, c 11.

See Re Curran, infra note 57.

2016 ONCA 196, 129 OR (3d) 561 [Spence].

7 For an example of balancing principles such as equality and freedom of contract see Aharon Barak "Constitutional Human Rights and Private Law" in Daniel Friedmann \& Daphne Barak-Erez, eds, "Human Rights in Private Law" (Portland OR: Hart Publishing, 2001) at 22.
} 


\section{II: SPENCE V. BMO TRUST CO.}

\section{A. The Application Decision}

Emanuel "Eric" Spence died in 2013. He was survived by his two daughters, Donna and Verolin, and their children. The evidence as accepted by the application judge was that while Mr. Spence had had a close relationship with his daughter Verolin, he had largely been estranged from Donna for most of her life. Mr. Spence had separated from his first wife and the mother of the two girls while they were still young children. It was Verolin who eventually moved from England to Canada to live with Mr. Spence while Donna remained in the U.K. with her mother. ${ }^{8}$ Despite this, when he died, Mr. Spence left his entire estate to Donna and her son. He also included the following clause in his will: "I specifically bequeath nothing to my daughter, Verolin Spence, as she has had no communication with me for several years and has shown no interest in me as a father."9

Verolin, however, believed that her father had cut her out of his will for a very different reason. She alleged that the real reason for her "disinheritance" 10 was that she had conceived a child with a man of a different race. Verolin's evidence was corroborated by a neighbor and friend of the testator. In both of their affidavits, they swore that Mr. Spence's decision to leave Verolin out of his will was based solely on the fact that the father of Verolin's son was white. ${ }^{11}$ Verolin alleged that after her father learned that she was pregnant and then learned the identity of the child's father, her relationship with her father dissolved. ${ }^{12}$ Verolin applied for the will to be set aside on grounds that it contravened public policy because the motivation behind the disposition of her father's estate was racist. ${ }^{13}$

In 2016, Spence was a case of first instance with respect to the application of public policy in the area of estate law. Traditionally, as discussed below, public policy's ambit with respect to private wills involved the voiding of problematic conditions on gifts, or of gifts to problematic beneficiaries. Here what the applicant sought was the voiding of an entire will because the alleged motivation behind it was discriminatory and therefore contrary to public policy. Additionally, in order to attribute a discriminatory motivation to the testator, the court needed to rely solely on extrinsic evidence to do so. As the respondent argued in Spence, in estate law, courts are rarely permitted to use extrinsic evidence or look beyond "the four corners of a will" to determine a testator's true intention. Some exceptions to this evidentiary rule exist but are generally restricted to courts of construction tasked with interpreting an ambiguous or uncertain testamentary passage, or to a court of probate determining issues related to validity. ${ }^{14} \mathrm{Mr}$.

\footnotetext{
Spence v BMO Trust Co, 2015 ONSC 615, 123 OR (3d) 611 at 22 [Spence SC].

$9 \quad$ Ibid at para 13.
}

10 Ibid at para 22. As noted throughout this article, there is no such thing as disinheriting someone in Ontario estate law. Apart from certain legislative stipulations concerning dependants or other matters of public policy, testators are free to leave their money to whom they like. The term however is used by the application judge in Spence and colloquially in this paper to describe the act of deliberately not leaving one's child anything in one's will, despite societal expectations to the contrary.

11 Ibid at para 26.

12 Ibid at para 19.

13 Ibid at Para 33.

14 Ibid at para 42. In estate law, the laws of evidence vary as between the courts of probate and construction. Probate courts may require extrinsic evidence of a testator's intention for reasons of validity such as testamentary capacity and undue influence. However, with respect to courts of construction, which are tasked with the interpretation of otherwise valid wills, "[e]xtrinsic evidence of direct intent will be rejected when there is a reasonable interpretation of the words that were actually used in the will. Resorting to the extrinsic evidence of direct intent would provide an inconsistent result with the reasonable interpretation of the words itself." TG Feeney, The Canadian Law of Wills, 4th ed (Toronto: Butterworths, 1987) at paras 10.24-10.28. The reasoning behind these two different evidentiary standards has to do with 
Spence's will had already been probated and contained no ambiguity or uncertainty. Indeed, the terms of the will were quite clear, expressly providing a specific and non-discriminatory reason why the testator left nothing to Verolin.

The application judge nevertheless agreed that the will contravened public policy, finding that the testator's true "reason for disinheriting Verolin" was based on racially motivated discrimination. ${ }^{15}$ Gilmore J.'s reasoning appeared to be based largely on the fact that Verolin's evidence went unchallenged by her sister Donna, who otherwise stood to inherit the entire estate, and that it was corroborated by a third party who had nothing to gain from the will being set aside. ${ }^{16}$ Justice Gilmore also accepted Verolin's arguments that the recent New Brunswick decision of McCorkill $\mathrm{v}$ McCorkill Estate ${ }^{17}$ could be relied upon as precedent for the principle that a clause in a will, free of any impugned terms or conditions, could nevertheless be found to contravene public policy. ${ }^{18}$ While Justice Gilmore acknowledged that traditional evidentiary rules in estate law generally prohibited the admissibility of extrinsic evidence to prove a testator's intention ${ }^{19}$, in her opinion the matter at issue in Spence merited "further scrutiny." 20 Justice Gilmore ordered that the entire will be set aside, which she noted resulted in an intestacy of the estate and an equal distribution of its assets to both sisters. ${ }^{21}$

\section{B. The Appeal}

Justice Gilmore's decision was reversed by the Ontario Court of Appeal. Justice Cronk, writing for the majority, provided what amounted to two separate rulings. One was based on the facts of Spence while the other concerned a hypothetical scenario. In both, Cronk J.A. held that "a public policy-based inquiry" was entirely unavailable to Verolin.

Justice Cronk provided three main arguments to support her conclusion with respect to the actual facts of Spence. First, despite the trial judge's use of the term "disinheritance", absent a clear gift to Verolin or her son in the will, neither Verolin nor her son had any legal entitlement to the testator's estate in the first place. ${ }^{22}$ Second, the will contained no conditions or instructions that offended public policy, the hallmarks of past testamentary clauses voided or amended in accordance with the doctrine. ${ }^{23}$ Third, the evidence upon which the application judge had based her decision was inadmissible. ${ }^{24}$ Justice Cronk concluded that the doctrine should not be expanded to apply to the motivations of a testator with respect to the disposition of his estate, absent an expressly discriminating condition or instruction on the face of the will. ${ }^{25}$

Justice Cronk's second finding concerned a hypothetical scenario that imagined a will to contain a clause similar to the one in Spence that expressly stated that nothing was to be left to Verolin, but was

the basic common law principle that a written, valid will is the baseline for the administration of estates. While it may be necessary to look beyond the will for evidence of a testator's intention if there are questions that concern matters of probate, external, non-testamentary documents should not be allowed to override the wishes of the testator if these are clearly discernable from the will itself. See Albert H Oosterhoff et al, Oosterhoff on Wills, 8th ed (Toronto: Thomson Reuters Canada, 2016) at 30-31, 439-440, 477-495.

$16 \quad$ Ibid at para 45.

172015 NBCA 50, 438 NBR (2d) 395, aff'g 2014 NBQB 148, 424 NBR (2d) 21 [McCorkill].

18 Spence SC, supra note 8 at paras $43-48$.

19 Ibid at para 42.

$20 \quad$ Ibid at para 44.

21 Ibid at para 50.

22 Spence, supra note 6 at para 51.

23 Ibid at 52.

24 Ibid at 53.

25 Ibid at paras 51-54. 
explicitly discriminatory in nature. Justice Cronk held that public policy was equally inapplicable in such a situation. ${ }^{26}$ In her reasons Justice Cronk maintained that her second, hypothetical scenario attracted the same reasoning as the factual component of her decision as it too represented just another example of a testator's "exercise of discretionary authority" that should be immune to public policy's scrutiny. ${ }^{27}$ She held that subjecting an unconditional testamentary clause that offered no form of entitlement, no matter how discriminatory in nature it might be, to public policy review, constituted an unwarranted intrusion upon the principle of testamentary freedom. ${ }^{28}$

Both rulings in Spence represent a clear limitation of the doctrine of public policy's application with respect to discrimination advanced through the mechanisms of private law. With respect to the ruling based on the case's actual facts, the outcome is likely correct, based on some of the reasons provided by Justice Cronk. However, the ruling based on Cronk J.A.'s hypothetical scenario is highly problematic. In short, the hypothetical ruling grants express permission for individuals to perpetuate discrimination through their private wills, an act that has the potential to inflict wide spread and detrimental consequences on Canada's multicultural society.

Before fully engaging with these arguments, a basic understanding of the doctrine, its history and its path towards combating discrimination in the private law in Canadian law is necessary. The following section provides a brief history of the doctrine and its past uses as well as a more detailed account of how it came to be applied to instances of discrimination in the private law in Canada.

\section{III: PUBLIC POLICY, DISCRIMINATION AND THE PRIVATE LAW}

\section{A. The History and Purpose of the Doctrine}

Though the term has many legal meanings, public policy is a distinct doctrine of the common law that allows a court to void the operation of otherwise lawful common law rules. As a legal concept, the doctrine has been traced by one author to the $13^{\text {th }}$ century. ${ }^{29}$ The earliest reported decisions attributed to public policy took place from the 1400s onward. These cases involved the voiding of contracts that sought to restrain trade ${ }^{30}$, or clauses in wills that contained restrictive conditions concerning a beneficiary's ability to marry. ${ }^{31}$ It was not until the $19^{\text {th }}$ century that jurists began to refer to a "doctrine of public policy", 32 and defined its purpose as ensuring "the common good of the community" 33 and its power as to render "void" that "which is against the public good." 34

26 Ibid at paras 71-75.

$27 \quad$ Ibid at para 84.

28 Ibid at paras 84-85.

29 This was the work of jurist Henry De Bracton, which included discussions of how the law should view impossible scenarios, or those "sacred things so valued by the public that they could never be subject to private ownership." See Percy H. Winfield's "Public Policy in the English Common Law" (1928) 42 Harv. L Rev 76 at 80, citing Henry De Bracton, De Legibus et Consuetudinibus Angliae (On the Laws and Customs of England), ed by George E Woodbine, Vol 1-2 (London: Humphrey Milford 1922).

30 Dyer's Case (1414), YB Anon 2 Hen V, pl 26, fol 5. See also, Mitchel v Reynolds [1711] Fortes Rep 296,24 ER 347 (KB).

31 Key v Bradshaw, [1689] 2 Vern 102, 23 ER 675 (Ch).

32 Notably the earliest cases attributed to applications of public policy do not use of the term "public policy" or recognize it as a doctrine of the common law at all with some of the earlier applications done in the Courts of Chancery. See Baker $v$ White, [1690] 2 Vern 215, 23 ER 740 (Ch).

33 Egerton, supra note 2 at 123.

34 Ibid at 140. 
As to what constitutes the "public good", texts and cases refer to any number of factors that inform a court's application of the doctrine, including legislation, constitutional law, political speeches and social morals. ${ }^{35}$ Specific factors that have guided past public policy decisions have ranged from Roman law, ${ }^{36}$ to the teachings of the Christian church, ${ }^{37}$ to the Charter of Rights and Freedoms. ${ }^{38}$ Arguably the only observation about the doctrine that applies to all its reported applications is its variable nature, ${ }^{39}$ a view perhaps best encapsulated by Justice McCardie of the English Court of King's Bench in an early $20^{\text {th }}$ century case:

The Courts have not hesitated in the past to apply the doctrine [of public policy] whenever the facts demanded its application... The truth of the matter seems to be that public policy is a variable thing. It must fluctuate with the circumstances of the time. The principles of public policy remain the same, though the application of them may be applied in novel ways. The ground does not vary. As it was put by Tindal C.J. in Horner v. Graves... "Whatever is injurious to the interests of the public is void, on the grounds of public policy." 40

Inevitably as the common law solidified and governments became more accountable to it ${ }^{41}$, the fact that the doctrine depended on a court's interpretation of it at any given time made it controversial in nature. From approximately the $19^{\text {th }}$ century onward, courts began to treat the doctrine with caution and at times mistrust, with one, oft-quoted decision, likening it to an unruly horse. ${ }^{42}$ Certainly, the principle of testamentary freedom remains an important and well recognized cornerstone of the private law. Courts are usually loathe to interfere with clear and otherwise legal conditions and clauses within a private will for that very reason. However, while applications of the doctrine to areas such as private wills and trusts remain infrequent, they have occurred since the $15^{\text {th }}$ century and continue to this day. Furthermore, past decisions that have sought to limit the doctrine with respect to what informs it, or how it can be applied, have inevitably failed, ${ }^{43}$ a point also observed by McCardie J. in his 1918 decision quoted above ${ }^{44}$, and discussed further below.

35 Bruce Ziff, The Principles of Property Law, $6^{\text {th }}$ Ed (Toronto: Carswell, 2014) at 257.

36 Stackpole v Beaumont, [1796] 3 Ves 89, 30 ER 909 at 913.

37 Rose M Trapani, "Conditions in Restraint of Marriage" (1939) 14:1 St John's L Rev 89 at 89, art 4.

38 Spence, supra, note 6 at para 97.

39 Winfield, supra note 29 at 93.

40 Naylor, Benzon and Co, Limited v. Krainische Industrie Gesellschaft, [1918] 1 KB 331 [Naylor], aff' d CA [1918] 2 KB 486 at 342-343. This reasoning was subsequently adopted by the English Court of Appeal and is cited in the first common law decision that held discrimination itself was contrary to public policy; Re Drummond Wren, [1945] OR 778, 1945 CarswellOnt 62 (H Ct J) [Wren cited to Carswell] at para 12. For more on this point, see Winfield, supra note 29 at 93-96.

41 As the $17^{\text {th }}$ century closed, significant changes occurred in the legal landscape of Great Britain. The least of these was the Glorious Revolution of 1688 and with it, the 1689 Bill of Rights 1689 (UK), 1 William \& Mary, c 2, s 2. Among other goals, the Bill of Rights sought to stop interference by the Crown with laws passed by Parliament and increase the integrity of statutory law. Coupled with this was an ever-increasing supply of reported case law. Thus, judges during this time had less cause to turn to reason, logic or "the greater good" when deciding a case. For more on this point see Winfield, supra note 29 at 84.

42 This quote is used by Justice Burrough in Richardson v Mellish [1825] 3 Bing 334, 171 ER 1179 (CP) but is attributed originally to Chief Justice Hobart, Winfield, supra note 29 at 88.

43 Winfield, supra note 29 at 94.

44 Naylor, supra note 40 at 342. 


\section{B. Public Policy, Discrimination and the Private Law in Canada}

Interestingly, among the countries of the British Commonwealth, the notion that particular instances of discrimination in the private law may be contrary to public policy remains uniquely Canadian. ${ }^{45}$ In particular, since at least the $17^{\text {th }}$ century, litigants in the U.K. have attempted to challenge testamentary clauses $^{46}$, contracts between individuals or the refusal to contract ${ }^{47}$ and charitable trusts ${ }^{48}$, on the basis that a clause, a policy or a condition was discriminatory and therefore contrary to public policy. None were successful in doing so. ${ }^{49}$ While some U.K. courts chose to void conditions on clauses pertaining to the "Jewish Faith" this was not because they contravened public policy but because they were deemed uncertain. ${ }^{50}$ Although one might believe that these "uncertainty" decisions were simply a roundabout way chosen by the English courts to deal with discriminatory clauses, at least one scholar has maintained that these decisions themselves were discriminatory in nature. Notably, it was only those clauses that sought to control a beneficiary's religion that concerned Judaism that were struck for uncertainty. Identical clauses concerning the Roman Catholic faith were held to be valid by the same courts. ${ }^{51}$ In a handful of other cases, clauses that sought to control the religion of children while still minors were found contrary to public policy, but only because these clauses were deemed an impermissible interference with the parental duty concerning a child's religious upbringing and education. ${ }^{52}$ Certainly, in no instance has a U.K. court declared discrimination itself to contravene public policy. ${ }^{53}$

45 With the exception of one decision from South Africa in 2006 where the High Court of South Africa expressly adopted the reasoning of Justice Mackay in Re Wren, supra note 40, (the Canadian case that constituted the very first finding that discrimination was contrary to public policy and one that is referred to throughout this article) to void discriminatory conditions on a scholarship established by way of testamentary trust: Minister of Education and another $v$ Syfrets Trust Ltd NO and another [2006] ZAWCHC 65; 2006 (4) SA 205 (C); [2006] 3 All SA 373 (C); 2006 (10) BCLR 1214 (C) at para 38.

46 Perrin v Lyon [1807] 9 East 170, 103 ER $538(\mathrm{~KB})$.

47 Nagle v Feilden [1966] 2 QB 633, [ 1966] 1 All ER 689 (CA) [Nagle].

48 Re Lysaght, Hill v Royal College of Surgeons (1965), [1966] Ch 191, [1965] 2 All ER 888 [Lysaght]. In this case the Royal College of Surgeons objected to a testamentary bursary established for its institution that excluded Jewish or Catholic applicants, calling the clause "so invidious and so alien to the spirit of the college's work as to make the gift inoperable in that form". The College argued that "religious discrimination was contrary to public policy". While the court exercised its use of the cy-pres doctrine to omit the offensive words from the bursary, it did so on the grounds of "impracticality" and it expressly held that they were not contrary to public policy; Ibid at 198-199.

49 While the litigant was successful in Nagle $v$ Feilden, which concerned a challenge to a membership requirement of a Jockey Club (the applicant was a woman who was banned from holding a membership reserved for men only) the actual decision of the case had more to do with monopolies and license holders acting in a capricious manner than voiding terms of a contract because they were discriminatory in nature; Nagle, supra note 47 at 693.

50 See Clayton v Ramsden, [1943] AC 320, [1943] 1 All ER 16 [Clayton cited to All ER]; See also Tarnpolsk, Re, Barclays Bank Ltd v Hyer, [1958] 3 All ER 479, [1958] 1 WLR 1157 (Ch); Re Blaiberg and Public Trustee v De Andia Yrarrazaval and Blaiberg, [1940] Ch 385, [1940] 1 All ER 632 at p. 391. - Contra Selby's Will Trusts, Re, Donn v Selby, [1965] 3 All ER 386, [1966] 1 WLR 43 (Ch); Tuck's Settlement Trusts, Re, Public Trustee v Tuck, [1978] Ch 49, [1978] 1 All ER 1047.

51 Herman Didi, An Unfortunate Coincidence: Jews, Jewishness, and English Law, $1^{\text {st }}$ ed (Oxford: Oxford University Press 2010).

52 See Re Borwick v Borwick, [1933] Ch 657, [1933] All ER 737 [cited to All ER] at 744-746; McCausland and Others v Young and Others, [1949] NI 49 (CA); See also Tegg, Re, Public Trustee v Bryant, [1936] All ER 878, 80 Sol Jo 552 at 879.

53 See also the Australian case Hickin v Carroll, [2014] NSWSC 1059 where the Supreme Court of New South Wales upheld a condition in a will requiring the beneficiaries, who were Jehovah's Witnesses, to convert to Roman Catholicism. Justice Kunc held that the Court was bound by the principles of testamentary freedom, and there was no support for the proposition that religious discrimination in wills was contrary to public policy. Likewise see Re Sutcliffe, 
The history of subjecting instances of discrimination in the private law to public policy evaluation dates back in Canada to at least $1888,{ }^{54}$ however, the case law only obtained a critical mass after 1990. Specifically, at least eleven instances of discrimination in private wills or trusts have been subject to a public policy inquiry after the passage of country-wide human rights legislation and the adoption of Canada's Charter of Rights and Freedoms ${ }^{55}$, both of which have been attributed as informing factors of the doctrine by appellate level courts in Canada. ${ }^{56}$

Indeed, with the exception of a $19^{\text {th }}$ century Quebec case, prior to 1945 Canadian courts were very much on par with their UK counterparts, holding that at most, clauses in wills that discriminated on grounds of religion were in keeping with public policy. Indeed, in 1939 the Ontario High Court of Justice held that a condition that sought to exclude any of the testator's grandchildren who renounced Catholicism or who married a non-Catholic, from inheriting her estate, was simply not a "question of public morality" and was "not a matter in which the public has the slightest concern." ${ }^{57}$ Notably that same year the Supreme Court of Canada held that denying a patron in a public establishment service because he was black, was also not contrary to public policy. ${ }^{58}$ Despite this, tolerance for discrimination in the private law was by no means steadfast during this era. For example, in 1911, Chief Justice Hunter of the British Columbia Supreme Court voided a restrictive covenant that forbade the sale of certain land to persons "of Chinese or Japanese origin". No reasons were given for the unreported, in-chambers decision. The only account of the case was provided by H.S. Robinson, the Registrar of Titles for the City of Vancouver, who published a short article in the Vancouver Advocate on the subject of racist land covenants 40 years later. ${ }^{59}$ Robinson believed the absence of reasons in Hunter C.J.'s decision was due to the "evil" of the issue being so obvious. ${ }^{60}$ In Robinson's opinion, the judgement merely gave effect to the fact that these covenants were never "worth the paper on which they were written". ${ }^{61}$ In the case of Re Drummond Wren, the first common law decision to hold that discrimination contravened public policy, ${ }^{62}$ an applicant seeking to have a discriminatory restrictive covenant declared void filed a supportive affidavit by the Master of Titles in Toronto. In it, the Master affirmed that he had "not knowingly permitted anyone to register deeds

[1982] 2 NZLR 330 for an example of the same principle in New Zealand and McCausland v Young, [1949] NI 49 in Northern Ireland.

54 In Kimpton, supra note 3 at 340, the Superior Court of Quebec invalidated a clause that provided a substitutionary giftover in favour of beneficiaries who "professed the Protestant religion" because it contravened a fundamental principle of Quebec's public policy. The Court held that the public policy ruling was informed by the freedom of religion guaranteed to all subjects of Quebec in chapter 74 of the Revised Statutes of Canada. The provision therefore constituted an impermissible "restriction of conscience".

55 Supra note 4.

56 Spence, supra note 6; McCorkill, supra note 17. For more on this point, see also S Grattan \& H Conway, "Testamentary Conditions in Restraint of Religion in the Twenty-First Century: An Anglo-Canadian Perspective” (2005) 50 McGill LJ 511.

57 Re Curran, [1939] OWN 191, 1939 CarswellOnt 167 (H Ct J) [Cited to Carswell] at para 3.

58 Christie v York Corp (1939), [1940] SCR 139, 1939 CarswellQue 46 [Christie cited to Carswell]

59 The unreported decision is reproduced in HS Robinson, "Limited Restraints on Alienation" (1950) 8 Advocate 250 at 251; It is referenced as Ref. Chamber applications VR 111/Fol 65 Jany. $11^{\text {th }} 1911$.

$60 \quad$ Ibid at 251.

61 According to Robinson, Hunter C.J.'s judgement had the effect of nipping the legitimacy of discriminatory restrictive covenants in the bud during a period of rapid development in B.C.'s lower mainland when such covenants began to materialize. To the best of Robinson's knowledge, even where such covenants had been successfully registered with the Land Titles Office in Vancouver, any conditions that limited the sale of the property to persons of a certain race or religion were considered void by city officials. Robinson claimed that as of 1950, there had never been a case where a Register of Titles had requested evidence of a grantee's skin colour or religion prior to perfecting a conveyance of property. Ibid at 251.

62 Supra note 40. 
containing restrictive covenants" that forbade the sale of land on the basis of a person's race, religion or ethnicity, and had "on several occasions refused to accept for registration documents containing such covenants, and in no case ha[d] an appeal been taken from such refusal." ${ }^{63}$ Re Wren is discussed further below.

The last Canadian decision where a court indicated that any discrimination based on race or religion was in keeping with public policy, was released in 1956. In the British Columbia case of Mindlin v. Hurshman ${ }^{64}$ a testator's will provided that a gift to his daughter be withheld from her and instead given to a charitable organization, if at the time of his wife's death, his daughter remained "the wife of a Jew". ${ }^{65}$ While the clause was ultimately voided on public policy grounds, these were based on the notion that any attempt to fracture a marriage was contrary to public policy. ${ }^{66}$ The closing paragraph of the decision demonstrated the motion judge's views on the current state of the law and what he saw as its increasingly poor fit in Canadian society:

I might add that any propensity toward racial discrimination has no place in this country and while it may be open to a testator to lay down the conditions upon which his children may or may not share in his bounty, yet insofar as those conditions involve racial discrimination, his language must be precise and explicit and clearly within the law if he expects the Courts to assist him in the fulfilment of his aims. ${ }^{67}$

Justice McInnes' stipulation for clear and precise language was in reference to the U.K. decisions where testamentary clauses that required a beneficiary to marry someone of, or adhere to, the "Jewish Faith" were voided for reasons of uncertainty ${ }^{68}$ While Justice McInnes may well have been signaling that a Canadian court would take any opportunity to void such obnoxious clauses, it was clear that he was resigned to the fact that discrimination itself in a private will was not contrary to public policy. ${ }^{69}$

Although not cited in Hurshman, Justice McInnes' belief was perhaps based on an earlier decision of the Ontario Court of Appeal in Noble v Alley ${ }^{70}$ where both the Ontario High Court of Justice and the Ontario Court of Appeal refused to find a racist restrictive covenant contrary to public policy. In determining that the covenant's terms forbidding sale to "any person of the Jewish, Hebrew, Semitic, Negro or coloured race or blood"71 was in keeping with the public policy of Ontario, the Court of Appeal overruled the earlier decision of Re Wren. As discussed above, in Re Wren, a similar covenant was found to contravene public policy because of its discriminatory nature. ${ }^{72}$ While the Ontario Court of Appeal's decision in Noble was ultimately overturned by the Supreme Court of Canada ${ }^{73}$, it was done so on grounds

$63 \quad$ Ibid at para 8.

64 (1956), 6 DLR (2d) 615, 1956 CarswellBC 235 (SC) [Hurshman cited to Carswell].

65 Ibid at para 1.

66 Ibid at para 10.

67 Ibid at para 13.

68 Supra note 50.

69 This is demonstrated largely by McInnes J.'s favorable reference to Lord Atkin's comments in the 1943, U.K. case of Clayton v Ramsden, supra note 50 at 325, which expressed the Lord Atkin's hope for legislation banning discriminatory conditions in wills.

70 [1949] 4 DLR 375, [1949] OR 503 (CA) [Noble CA].

71 Re Noble and Wolf, [1948] OR 579, 1948 CarswellOnt 58 (H Ct J) at paras 1 - 7 [Noble cited to Carswell].

72 Supra note 40.

73 Noble v Alley (1950), [1951] SCR 64, 1950 CarswellOnt 127 [Noble SCC]. 
unrelated to public policy, with the Supreme Court never pronouncing one way or another on the issue. ${ }^{74}$ It would take 40 years for the Ontario Court of Appeal to weigh in again on whether discrimination in the private law was capable of contravening public policy and, in doing so, reverse its own precedent.

\section{Canada Trust Co. v. Ontario}

It is impossible to discuss public policy and discrimination in Canada without a somewhat detailed account of Canada Trust Co. v. Ontario Human Rights Commission. ${ }^{75}$ This is because the 1991 Ontario Court of Appeal decision cemented the notion that certain instances of discrimination in the private law were contrary to public policy in Canada but, in doing so, left significant questions concerning the doctrine's application to matters of private law. From it followed the bulk of case law related to public policy and discrimination in Canadian private law.

The case concerned the Leonard Foundation scholarship, a public bursary established by way of a testamentary trust in $1923 .^{76}$ Qualified recipients had to be white, protestant, British or of British parentage. Further, on any given year, at most only $25 \%$ of the available income of the trust could be used to fund female recipients of the scholarship. The trust contained recitals that expounded the virtues of the British Empire and the fact that the progress of the world depended upon the Christian faith and the white race. ${ }^{77}$ While the Ontario Superior Court found the impugned terms valid ${ }^{78}$, the conditions were ultimately voided by the Ontario Court of Appeal for contravening public policy.

The Court of Appeal's decision was unanimous in result but split with respect to how the doctrine of public policy should be applied to instances of discrimination in the private law. On finding that the trust contravened public policy, the majority's decision held that to do so was "to expatiate the obvious." 79 It was a principle of public policy that all religions were to be accorded equal regard and respect. ${ }^{80}$ Further, they held that while the freedom of testamentary disposition was "an important social interest" it was one that, in the case at bar, must be limited in accordance with "public policy considerations". ${ }^{1}$

74 Ibid at para 20.

75 (1990), 74 OR (2d) 481, 1990 CarswellOnt 486 [Canada Trust Co cited to Carswell].

76 For a detailed account of Colonel Reuben Wells Leonard see

Bruce Ziff, Unforeseen Legacies: Reuben Wells Leonard and the Leonard Foundation Trust (Toronto: University of Toronto Press, 2000).

77 Canada Trust Co, supra note 75 at para 74.

78 The case was initiated by the foundation's trustees who applied for advice to the Superior Court of Ontario. They asked whether the trust was in contravention of the province's Human Rights Code. Justice McKeown of the Ontario Superior Court found that the scholarship did not contravene public policy. Citing the Supreme Court in Re Millar, infra note 186, he found that the harm done to the Ontario public was not "so obnoxious to the public good that the rules of law governing testamentary trusts cannot have their normal operation". He also cited the English case of Lysaght, supra note 48 at 198 where a similar clause in a bursary was expressly held not to violate public policy; Canada Trust Co v Ontario Human Rights Commission (1987), 61 OR (2d) 75, 1987 CarswellOnt 651 at para 46 [Canada Trust SC cited to Carswell].

79 Canada Trust Co, supra note 75 at para 39.

$80 \quad$ Ibid at para 40.

$81 \quad$ Ibid at para 37. 
In his concurring opinion Tarnopolsky J.A. cited a variety of modern factors ${ }^{82}$ that he believed informed and dictated public policy, including the recently enacted Charter of Rights and Freedoms. ${ }^{83}$ Justice Tarnopolsky held that the harm of such discrimination, if allowed to exist within facets of the private law, was "substantially incontestable." 84 This was especially so given the multicultural nature of Canadian society. ${ }^{85}$ As noted above, this was not the first time the Ontario Court of Appeal had been asked to find discrimination of this nature to be contrary to public policy. In the 1948 decision of Noble v. Alley ${ }^{86}$ the Court had found a similar kind of racism attached to a restrictive covenant to be in keeping with public policy. In doing so it had expressly overturned the earlier, Ontario High Court of Justice decision of Re Wren, ${ }^{87}$ a decision of first instance. In Re Wren Justice Mackay explained how harmful discrimination in the area of property law based on race, religion and ethnicity was to the basic notion of national unity in Canada. He believed that nothing could "be more calculated to create or deepen divisions between existing religious and ethnic groups" 88 in Ontario or Canada. Written in 1945, Justice Mackay's reasons alluded to the similar and costly lesson learned from the horrors of Nazi Germany, where such discrimination had been allowed to fester and grow within all facets of the law. ${ }^{89}$ In Noble, the Ontario Court of Appeal dismissed Justice Mackay's reasoning. The five judge panel unanimously endorsed the motion judge's decision in Noble which found that Re Wren relied too much on international treaties and the policies of other countries, ${ }^{90}$ and that Mackay J.'s judgement represented an "arbitrary extension" of the doctrine 91 and created an impermissible "novel head of public policy." 92 At the appellate level, Henderson J.A. held that the judgement in Re Wren was "wrong in law and should not be followed". 93 Further, the Chief Justice of the Ontario noted that while "goodwill and esteem among the people of the numerous races that inhabit Canada" was a laudable goal, to legislate such tolerance would be meaningless if the targets of such legislation did not genuinely share such a view. ${ }^{94}$

Forty years later, Tarnopolsky J.A. affirmed and adopted Justice Mackay's judgement in Re Wren, applying it to the area of trust law. Justice Tarnopolsky quoted Mackay's J.'s decision verbatim, writing

82 These included declarations by the then Premier of Ontario concerning the government's aim to combat all forms of racism, noted the observations of Wilson J.A. (as she was then) in Seneca College of Applied Arts \& Technology (Board of Governors) v Bhadauria (1979), 27 OR (2d) 142, 105 DLR (3d) 707, who equated the preamble of Ontario's Human Rights Code with the public policy of Ontario and referenced a similar observation made by the Supreme Court of Canada in Ontario Human Rights Commission v Borough of Etobicoke, [1982] 1 SCR 202, 132 DLR (3d) 14 at 23-24: ibid at paras 95, 98. Like Justice Mackay in Wren, Tarnopolsky J.A. also cited additional, non-human-rights-oriented statutes as reinforcing the message that the kind of discrimination at bar was contrary to public policy. These included s 13 of the Conveyancing and Law of Property Act, RSO 1980, c 90; s 4 of The Ministry of Citizenship and Culture Act 1982, SO 1982, c 6; s 117 of the Insurance Act, RSO 1980, c 218; and s 13 of the Labour Relations Act, RSO 1980, c 228: Wren, supra note 40 at para 97.

83 Supra note 4.

84 Canada Trust Co, supra note 75 at para 96.

85 Ibid.

$86 \quad$ Noble CA, supra note 70.

87 Wren, supra note 40.

88 Ibid at para 20.

89 Ibid at paras 24-26.

$90 \quad$ Noble, supra note 71 at paras 38-43.

91 Ibid at para 51.

92 Ibid at para 44.

93 Noble $C A$, supra note 70 at para 32.

$94 \quad$ Ibid at para 29. 
that he could "think of no better way" to convey the point that "the promotion of racial harmony, tolerance and equality is clearly and unquestionably part of the public policy of modern day Ontario." 95

However, while concurring on the fact that the scholarship at issue violated public policy, the majority and minority in Canada Trust Co. took two different approaches to the scope of the doctrine's application with respect to future applications of it to the private law. Driving this divide appeared to be what effect such a rule would have on other existing and future scholarships established to assist religious and racial minorities. ${ }^{96}$ The majority's solution was that in order for public policy to apply to a private law matter, the discrimination at issue had to be of a certain degree, determinable on a case by case basis. In the case at bar, Justices Robins and Osler found the blatant racism of the trust's recitals to be incompatible with public policy. ${ }^{97}$

The majority's decision, however, required it to view the trust's recitals as part of the trust itself. As noted by Justice Tarnopolsky and the motion judge, trust recitals are generally viewed as indicating motive only and irrelevant to determining the validity of a trust. ${ }^{98}$ In his concurring decision, Tarnopolsky J.A. found no reason to resort to the recitals. He believed that the trust itself was offensive to public policy as it contained discriminatory conditions of eligibility based on race, religion, and nationality. He found so, however, only on the added caveat that it was the "public nature" of the charitable trust which required it to "conform to the public policy against discrimination." 99 Justice Tarnopolsky expressly stated that his decision did not affect "private family trusts" "testamentary dispositions" or "outright gifts" of a private nature. $^{100}$

The split between the majority and minority decisions in Canada Trust Co. has yet to be addressed by the Supreme Court of Canada. The case was not appealed and no other case regarding public policy and discrimination in the area of wills, trusts or any other facet of the private law ${ }^{101}$ has been heard by the Canada's highest court since that time. However, in the cases that have since followed, both superior and appellate level courts have heard public policy applications not only in the areas of charitable trusts, but also concerning clauses in wills and private family trusts. Further, while not every one of these applications of public policy has resulted in the voiding of the impugned provision, none of these decisions - with the exception of Spence - held that a provision of a trust or a will was immune from the doctrine's scrutiny altogether.

\section{The Charitable Trust Cases}

Four decisions concerning discriminating, charitable trusts established through private estates have been reported since Canada Trust Co. The cases of Ramsden Estate, Re, ${ }^{102}$ and University of Victoria Foundation v. British Columbia, ${ }^{103}$ involved scholarships that required recipients to be members of a

95 Canada Trust Co, supra note 75 at para 96.

96 Ibid at para 42.

97 Ibid at paras 31-35.

$98 \quad$ Ibid at para 88.

99 Ibid at para 107. A reliance on the public nature of the scholarship was the alternative reasoning of the majority in the instance that the recitals could be severed from the trust, Ibid at para 35.

100 Ibid. As an additional way of limiting the scope of the decision, Tarnopolsky J.A. believed that any public policy finding in this regard should be determined in accordance with "an equality analysis like that adopted by the Human Rights Commission when approaching ss. 1 and 13 of the Human Rights Code, 1981, and that adopted by the courts when approaching s. 15(2) of the Charter." Canada Trust Co, supra note 75 at para 104.

101 to which human rights legislation does not apply.

102 (1996), 145 Nfld \& PEIR 156, 1996 CarswellPEI 98 (SC (TD)) [Ramsden cited to Carswell].

103 (Attorney General), 2000 BCSC 445, 73 BCLR (3d) 375 [Victoria Foundation]. 
specific religion. Esther G. Castanera Scholarship Fund, Re ${ }^{104}$ concerned two scholarships reserved exclusively for female candidates pursuing specific kinds of science degrees. Finally, Royal Trust Corp. of Canada v. University of Western Ontario ${ }^{105}$ involved a scholarship that sought to discriminate on a number of immutable grounds including race and sexual orientation. ${ }^{106}$

In all of these cases, a court was asked to determine whether conditions attached to a scholarship which discriminated on grounds such as religion, race or sex was void for reasons of public policy. As noted above, in none of these cases did a court declare that discrimination was immune from a public policy application. Rather, in each case the presiding court did one of two things. It either held that certain conditions in a scholarship violated public policy because they demonstrated a clear intention of a testator to discriminate in a way that contravened public policy ${ }^{107}$ or it declined to do so because it was, in the opinion of the presiding judge, clearly not the intention of the testator to discriminate in a manner that ran contrary to public policy. ${ }^{108}$ With respect to the actual outcomes of a public policy application, these cases are few but suggest an interesting trend: allowing the concept of direct, instead of adverse effect discrimination, to dictate a public policy finding with respect to charitable trusts. While this observation is likely the subject of another paper, what remains clear is that not one of these decisions disputes the idea that public policy is applicable to testamentary trusts or that certain specific instances of discrimination within them clearly contravene public policy.

\section{The Private Trust and Wills Cases}

The application of public policy to the charitable trust cases reviewed above did not require lower courts to choose between the majority and minority views in Canada Trust Co. with respect to the doctrine's applicability to discriminatory provisions in private wills and trusts. However, the rest of the jurisprudence that has amassed since that decision suggests that public policy is applicable to private wills and trusts when used to perpetuate discrimination.

The Supreme Court of Newfoundland case of Murley Estate v. Murley ${ }^{109}$ was decided five years after Canada Trust Co. The case concerned a testamentary clause that threatened to void a gift to the testator's son if he joined a religion such as "Pentecostals, Seventh Day Adventists, Jehovah Witnesses or Latter Day Saints, so called". ${ }^{110}$ According to the terms of the will, of primary concern to the testator was that his son remain associated with the Roman Catholic, Anglican or United Church of Canada as these would make him "a real Christian". ${ }^{111}$ Riche J. held that "such a provision which restricts the religious affiliation of any person [was], in Canada, contrary to public policy." 112 The clause was voided but Justice Riche provided no authority for his decision. ${ }^{113}$ The decision was not appealed.

1042015 MBQB 28, 314 Man R (2d) 291 [Castanera].

1052016 ONSC 1143, 129 O.R. (3d) 772 [Royal Trust].

106 And also, curiously, "anyone who play[ed] intercollegiate sports" Ibid at para 8.

107 Ibid at para 14.

108 Ramsden, supra note 102 at para 13; Victoria Foundation, supra note 103 at 24; Castanera, supra note 104 at para 27.

109 (1995), 130 Nfld \& PEIR 271, 1995 CarswellNfld 143 (SC (TD)) [Murley].

110 Ibid at para 4.

111 Ibid at para 1.

112 Ibid at para 6.

113 Even though no precedent was cited by Richie J., interestingly, precedent in Canada did exist for the decision. Apart from the majority's decision in Canada Trust Co., two Quebec decisions had found similar clauses in private wills contrary to public policy on the grounds that they sought to restrict a beneficiary's freedom of religion. See Kimpton, supra note 3, and Klein v Klein (1966), [1967] CS 300, 1966 CarswellQue 109. While these two decisions were decided under a codified provision of Quebec's Civil Law [then] Article 760 which provided that a condition "contrary to good morals, to law or to public order" voided a gift in a will, this term had been equated to the common law doctrine of 
A year later the Ontario Court of Appeal released its decision in Fox v. Fox Estate ${ }^{114}$ where an executor used her powers as estate trustee to disinherit her son. The son alleged that this action was based on him marrying outside the family's religion. ${ }^{115}$ Although the decision was ultimately decided on issues related to trust law, ${ }^{116}$ in a concurring opinion, Justice Galligan found that the executor's actions constituted a breach of public policy. Citing the majority decision in Canada Trust Co., Galligan J.A. stated that it was "now settled that it is against public policy to discriminate on grounds of race or religion." 117 Specifically he found that "it would be contrary to public policy to permit a trustee effectively to disinherit the residual beneficiary because he dared to marry outside the religious faith of his mother." 118 Notably, Justice Galligan made no mention of Justice Tarnopolsky's views on the doctrine's application to private wills. In 2009, the Supreme Court of Nova Scotia reviewed a testamentary provision that instructed the executor to restrict the sale of the testator's land to Anglican or Protestant persons. ${ }^{119}$ In his decision, Justice MacAdam engaged in a lengthy discussion of public policy and discrimination, referencing the cases of Canada Trust Co., Ramsden Estate and University of Victoria. ${ }^{120}$ After finding that the clause instructed the estate trustee to contravene the Nova Scotia Human Rights Act, the clause was voided accordingly. ${ }^{121}$

No subsequent cases were reported until 2014 when, six months prior to the release of Spence, a woman in New Brunswick applied to have a testamentary gift to a white supremacist organization in Virginia declared void for reasons of public policy. This case would be the first case since Canada Trust Co. that engaged substantively with the notion of public policy and discrimination, this time focused on the area of estate law and gifts in private wills.

McCorkill v. McCorkill Estate ${ }^{122}$ was released in January of 2014. At issue was the will of Harry Robert McCorkill. In it he gifted the residue of his estate, worth approximately $\$ 250,000$, to a white supremacist organization based in Virginia, U.S.A. Specifically the bequest directed that the residue be given "to the NATIONAL ALLIANCE". ${ }^{123}$ Mr. McCorkill's sister challenged the validity of the will on the basis that the gift was illegal and/or contrary to public policy. ${ }^{124}$ The Centre for Israel and Jewish Affairs, the League for Human Rights of B'nai Brith Canada, the Canadian Association for Free

public policy by the Supreme Court in the earlier decision of Renaud v Lamothe (1902), 32 SCR 357, 1902 CarswellQue 17. There the court, dealing with a similar provision of the Civil Code, stated the following "L'ordre public ou social l'intérêt général — public policy — Voilà de grands mots, assez vagues, qui en droit doivent avoir cependant une signification définie." At para 6.

114 (1996), 28 OR (3d) 496, 1996 CarswellOnt 317 (CA), leave to appeal to SCC refused, 207 NR 80 (note) [Fox Estate cited to Carswell].

115 Ibid at para 7.

116 Although the testator's will granted Miriam Fox, as executor and trustee, an absolute discretion to encroach on the capital of the estate for the benefit of her grandchildren, the Court of Appeal found that she had acted inappropriately in transferring her son's share of the estate to the grandchildren and ordered her removed as executor. It also ordered a reversal of her actions concerning the estate. Of the three separate, concurring decisions in Fox Estate, all found that Miriam Fox had encroached on the capital of the estate in an improper manner, treating the assets as her own when in reality she had been given a life estate with the residue to go ultimately to her son and not her grandchildren. Additionally, all three judges agreed that if the sole motivation for her encroaching on the capital was in retaliation for her son marrying outside of Jewish faith, this constituted a breach of trust as it was an improper exercise of her discretion to encroach: Ibid at paras 43, 53 .

117 Ibid at para 16.

118 Ibid at para 18.

119 Peach Estate (Re), 2009 NSSC 383, [2009] NSJ 643 at paras $19-23$.

120 Ibid at paras $18-28$.

121 Ibid at para 28.

122 Supra note 17.

123 Ibid at para 2.

124 Ibid at para 5 . 
Expression [CAFÉ], and the Province of New Brunswick, were granted intervener status in the case. With the exception of CAFE, all of the interveners argued that the bequest should be voided for reasons of public policy.

In his reasons, Justice Grant of the New Brunswick Queen's Bench provided an extensive review of evidence submitted by all parties and interveners, including the National Alliance's founding documents, its membership requirements, music production and a transcript of a radio broadcast by its current leader. Grant J. then concluded, based on this evidence, that the raison d'être of the National Alliance was to promote and disseminate racism, violence and hate speech. ${ }^{125}$ Reproducing Justice Tarnopolsky's passage in Canada Trust Co. concerning what informed public policy, Justice Grant also cited Canada's hate speech laws as an additional source of the doctrine with respect to the facts before him. ${ }^{126}$ Grant J. found that propagation of hate speech, a criminal offence in Canada if not in the U.S.A., was a major purpose of the National Alliance. Additionally he held that its "various communications and activities" contravened the values enshrined in Canada's constitution, human rights legislation and in its international commitments. These two facts rendered its activities contrary to public policy. It followed then, that a testamentary gift to such an organization was also contrary to public policy. ${ }^{127}$

Like Re Wren and Canada Trust Co. before it, and as Spence would be soon after, McCorkill was a case of first instance with respect to public policy, discrimination and the private law. Prior to this decision, regardless of the specific public policy concern, when applied to wills the doctrine had been used only to strike offensive conditions from gifts. The gift in McCorkill however was absolute in nature with no conditions attached. Apart from the public policy-based rule that a person who murders a testator cannot inherit from that testator's estate ${ }^{128}$, no court in the Commonwealth had voided an absolute gift due to the nature of the beneficiary. ${ }^{129}$

While Justice Grant recognized the significant leap between pronouncing the activities of the National Alliance contrary to public policy and issuing a similar judgement against an unconditional, testamentary gift to the organization, his reasons downplay the significance of his judgement. ${ }^{130}$ Specifically, Grant J. attempted to diminish the novelty of his public policy application by framing it as a very minor extension of past applications of the doctrine. He reasoned that the case was "comparable" to conditional bequest cases in that it could be reasonably inferred by the court that Mr. McCorkill's intention was that his gift be used in a manner that furthered the National Alliance's agenda. ${ }^{131}$ This was because the gift was made to the organization, not to one of its individual members or its lawyer. As an organization, the National Alliance came with founding documents that dictated its clear purpose. ${ }^{132}$ Despite this reasoning, McCorkill clearly represents an expansion of the doctrine's application, not simply with respect to discrimination in the private law, but to the kinds of testamentary clauses that have been voided for contravening public policy for any reason.

Writing on the decision in 2014, Professor Bruce Ziff likened the result in McCorkill to a welcoming of the "newest unworthy heir" to the exclusive club or persons unable to inherit an otherwise valid,

125 Ibid at paras 48, 54-56.

126 Criminal Code, RSC 1985, c C-46, s 319.

127 McCorkill, supra note 17 at para 63.

128 See Brissette $v$ Westbury Life Insurance Co, [1992] 3 SCR 87 at paras 8-9.

129 As Prof. Ziff notes, another beneficiary unable to receive a testamentary gift is likely an identified terrorist organization and this would run contrary to the criminal law. Bruce Ziff, "Welcome the Newest Unworthy Heir" (2014) 1 ETR (4 $\left.4^{\text {th }}\right)$ 76 [Ziff "“Unworthy Heir"].

130 McCorkill, supra note 17 at paras 64, 72.

131 Ibid at 77.

132 Ibid. 
testamentary gift. ${ }^{133}$ In his article, Prof. Ziff expressed some concern at the open-endedness of the McCorkill decision, wondering who else might qualify as unworthy. ${ }^{134}$ In a separate article, Professor Adam Parachin noted the absence of concrete evidence with respect to the National Alliance's purpose, such as the organization's corporate objects. Absent such evidence, Prof. Parachin questioned whether or not Justice Grant was able to find that the National Alliance would have been compelled to use Mr. McCorkill's gift in a manner contrary to Canadian public policy. ${ }^{135}$ By extension, he argued, unconditional bequests to racist persons could also be voided on similar grounds. ${ }^{136}$

While $M c$ Corkill was affirmed without reasons on appeal ${ }^{137}$, the inarticulate premise that bolstered the application of the doctrine in the decision could well have been the support of the New Brunswick Government itself. As noted above and as will be discussed further below, the doctrine of public policy has consistently attracted criticism of judicial activism since the $19^{\text {th }}$ century, with jurists arguing that decisions made under the doctrine were best left to elected legislators. Here however, the legislator who had the power to amend the New Brunswick Wills Act ${ }^{138}$ and provide for the result in McCorkill by way of legislation, opted instead to be an intervener in the case. The Province's position in McCorkill was that the gift to the National Alliance should be voided for contravening the public policy of the province. ${ }^{139}$

On this point, Justice Grant wrote:

It would not be practical for legislatures to pass legislation dealing with individual wills. An intervention such as this by the Attorney General is the only practical way for a government to deal with a particular case in order to ensure that the principles set out in legislation such as the Human Rights Act, supra., are upheld. That intervention sends a strong message about the effect of this bequest on the public policy of this province. ${ }^{140}$

The affirming decision of the New Brunswick Court of Appeal of McCorkill was released two weeks after the lower court decision of Spence. ${ }^{141}$ Three months later, the Ontario Court of Appeal released its decision overturning the application judge's ruling. Both appellate decisions were appealed to the Supreme Court of Canada. Leave to appeal was refused on both. ${ }^{142}$ While the outcome of that inquiry in McCorkill is subject to reasonable disagreement and critique by scholars like Parachin and Ziff, it was the availability of the inquiry itself in the context of an unconditional gift that serves as the case's basic ratio.

The remainder of this article reviews the decision of the Ontario Court of Appeal in Spence, that takes the opposite approach of $M c$ Corkill with respect to the availability of a public policy inquiry with respect to discrimination in a private will. Specifically it looks in detail at the two rulings in Spence and explains why the factual one is likely correct based on a combination of factors, while the ruling based on Cronk J.A.'s hypothetical is problematic.

133 Ziff, “Unworthy Heir”, supra note 129.

134 Ibid.

135 Adam Parachin, "Discrimination in Wills and Trusts" (20 September 2015), online: SSRN: $<$ https://ssrn.com/abstract $=2579844>$ at 33 .

136 Ibid at 36.

137 Supra note 129.

138 RSNB 1973, c W-9.

139 Supra note 17 at para 82.

140 Ibid.

141 Supra note 8.

142 Verolin Spence, et al v BMO Trust Company, 2016 ONCA 196, leave to appeal to SCC refused, 36904 (2016-06-09); Canadian Association for Free Expression - and - Fred Gene Streed, Executor of the Estate of Harry Robert McCorkill (a.k.a. McCorkell), deceased, et al., 2015 NBCA 50, leave to appeal to SCC refused, 36658 (2016-06-09). 


\section{IV: SPENCE REVISITED}

\section{A. On the Facts}

Recall that the actual facts of Spence involved the decision of a testator to provide for only one of his adult, independent children in his will. He also included a clause in his will that expressly stated that he was leaving nothing to his other child because she had shown no interest in him as a father.

That other child, Verolin Spence, alleged that the real reason her father left her out of his will was to punish her for having a child with a white man. Her evidence was corroborated by an uninterested third party, and was uncontested by her sister Donna, who otherwise stood to inherit the entire estate. The application judge found that the testator's disinheritance of Verolin was motivated by racism. She set aside the entire will on the grounds of public policy. Justice Cronk overturned the application judge's decision finding that the doctrine had no application to such a scenario. This finding was likely correct for the following reasons.

First, in accordance with the principles and policies that govern the law of wills and estates, the evidence that established Eric Spence's discriminatory intent was inadmissible. In reasons separate from her public policy ruling, Justice Cronk concluded that the evidentiary rules that pertained to courts of construction $^{143}$, in place for fundamental reasons of reliability and certainty ${ }^{144}$, also applied to public policy motions. ${ }^{145}$ Additionally, even if such evidence could be admitted, the discrimination at issue was advanced not through an active use of the private law, but rather a non-action to which there was no corresponding legal duty to act. In this case, the inaction was Mr. Spence's decision not to leave one of his daughters anything by way of his will. As Justice Cronk correctly noted in her reasons, no legal duty exists in Ontario for parents to provide for their independent, adult children in their wills. ${ }^{146}$ Therefore, on its facts, and given that the decision is based on the laws of Ontario, public policy had no applicability in this scenario as there was no use of the private law to which a public policy application, or any legal scrutiny for that matter, could attach. Notably, one of Justice Cronk's reasons for this portion of her

143 Oosterhoff, supra note 14.

144 The leading case in Ontario concerning this rule is Robinson Estate v Robinson, 2011 ONCA 493, [2011] OJ No 3084, leave to appeal to SCC refused, [2011] SCCA No 536. In his reasons in Robinson Estate, Juriansz J.A. noted that law reforms suggesting a more liberal approach to the issue of testator intent and extrinsic evidence in a court of construction had been expressly rejected by the Province of Ontario which, in his opinion, was for good reason; to allow extrinsic evidence (that contradicted what was in the testator's will) to prove a testator's true purpose in a court of construction would result in courts clogged with litigants whose main applications were based upon the premise of "he really meant me." at para 34. Even though the case at bar was neither one of construction nor probate, Justice Cronk held that the extrinsic evidence rule outlined in Robinson Estate should also apply to instances of public policy applications. She reasoned that if extrinsic evidence of a testator's direct intention was impermissible for the reasons outlined by Justice Juriansz in Robinson Estate, then the case for extrinsic evidence of a testator's motivations was even less compelling as it would replicate the problems outlined in Robinson Estate and likely exacerbate them. The Supreme Court of Canada has recently opined on the power of a court to rectify contracts and trusts, reiterating that this power is limited to those instances where there was a mistake with respect to recording the "originally intended mechanism" of the parties or the settlor. Unintended consequences of a correctly recorded mechanism are not sufficient reasons for a court to modify a valid contract or trust document. In the Court's view, a looser approach to rectification would undermine the confidence of society in the validity of such instruments. See Canada (Attorney General) v Fairmont Hotels Inc, [2016] 2 SCR 720 at paras 13 and 21.

145 Spence, supra note 6.

146 Ibid at para 32. Whether or not Verolin and her son could have made a Dependent's Relief Claim under Ontario's Succession Law Reform Act, RSO 1990, c S-.26. against her father's estate is unknown. At trial, she applied for an extension of the time period for applying on behalf of her son but was denied this request by the superior court; Spence SC, supra note 8 at paras $3-5$. She did not appeal this finding, Spence, supra note 8 at para 22. 
decision, the lack of precedent to support a novel application of the doctrine, is not persuasive. This argument is addressed below with respect to Justice Cronk's hypothetical ruling.

This being said, the validity of even this portion of Justice Cronk's decision may diminish as evidentiary rules and legislative obligations related to wills and estates in Ontario and elsewhere in Canada continue to evolve. Notably, British Columbia has long had legislation that allows the adult independent children of a testator to challenge a perceived disinheritance on moral grounds. ${ }^{147}$ The line to be drawn with respect to the availability of a public policy inquiry concerning discrimination and estate law is therefore much less clear in jurisdictions like British Columbia. This is especially so given that British Columbia has amended its estate legislation to expand the admissibility of extrinsic evidence for the purpose of proving a testator's intention. ${ }^{148}$ Finally, recent decisions have also called for a more flexible approach within the common law when it comes to the rules of evidence in estate law, drawing an analogy to the evolution of hearsay evidence in Canadian jurisprudence. ${ }^{149}$

Justice Cronk's decision in Spence concludes with her statement that "on the facts of this case there was no foundation for the public policy-driven review undertaken by the application judge." 150 This statement might be enough for some to conclude that the hypothetical portion of Spence is simply obiter. This is unlikely however given the extensive reasoning and clear conclusion that follows Justice Cronk's hypothetical in her decision. For those who agree with the latter sentiment, the rest of this section explains why the second, hypothetical-based portion of her reasons should not be followed.

\section{B. The Hypothetical}

After finding that the actual facts of Spence precluded any possible application of public policy, Justice Cronk then posed the following question in her reasons:

As I have said, Eric's Will does not "facially offend public policy." But what if it did? Was it open to Eric to disinherit Verolin in his Will on discriminatory grounds, that is, on the express basis that the father of her son was a white man, without triggering review by the courts on the grounds of public policy? ${ }^{151}$

Justice Cronk's response to her own question was that such clauses, no matter how discriminatory in nature, should never be subject to public policy. ${ }^{152}$ From the passages that follow her hypothetical, it appears that Justice Cronk largely applied her reasoning concerning the facts of Spence to her hypothetical scenario as well. This was an error as the two are fundamentally different in nature.

\section{A Conflation of Two Scenarios}

The basis of Cronk J.A's hypothetical-based ruling, at its core, appears to be that public policy is inapplicable with respect to a testator's right to choose his or her beneficiaries. ${ }^{153}$ This logic, while justified on the actual facts of the case, fails to track onto her hypothetical. This is because her hypothetical

147 Tataryn v Tataryn Estate, [1994] 2 SCR 807. 1994 CarswellBC 1243.

148 Wills, Estates and Succession Act SBC 2009, c 13. Notably, Alberta has also made similar amendments to its admissibility of evidence laws in estate matters: Wills and Succession Act SA 2010, c W-12.2 s. 26.

149 Lecky Estate v Lecky, 2011 ABQB 802, 2011 CarswellAlta 2230 at paras 69, 71- 76, 79-83, 85 [Lecky cited to Carswell]; as cited in Oosterhoff, supra note 14 at 487-498.

150 Spence, supra note 6 at para 86.

151 Ibid at para 72, emphasis added.

152 Ibid at para 75.

153 Ibid at paras 73-75. 
scenario is less about a testator's right to choose his heirs, and more about the use of a will and, in many circumstances, the courts of justice, to perpetuate discrimination that has been found to be at odds with the functioning of Canadian society.

The disconnect is made clear by Justice Cronk's review of Fox Estate. In her reasons, Cronk J.A. stated that Fox Estate was not helpful to any argument of the respondents because it concerned the powers of a trustee rather than the rights of a testator. She included a paragraph from Justice Galligan's judgement in Fox Estate to illustrate her point:

It is of course a given, assuming testamentary capacity, that a person is entitled to dispose of property by will in any fashion that he or she may wish. The exercise of a testator's right of disposition is not subject to supervision by the court. But a trustee's exercise of discretion is subject to curial control. Admittedly, because he would not be subject to judicial supervision, Ralph, if alive, could have disinherited Walter for reasons which would have contravened public policy. ${ }^{154}$

Certainly Justice Cronk's interpretation of this passage, that no parent in Ontario has a legal obligation to leave an adult independent child anything by way of will, is correct. However, it appears that Justice Cronk may have conflated Justice Galligan's acknowledgement of this fact with the issue of actively using one's will to punish, bully and discriminate against others. Justice Cronk's hypothetical involved the testator in Spence disinheriting his daughter "in his will on discriminatory grounds". ${ }^{155}$ Her hypothetical does not simply concern the choice to abstain from leaving a gift in a will, but the active use of the private law to discriminate against another by including a testamentary clause that, in her words, "facially offend[s] public policy". ${ }^{156}$ Notably Justice Cronk did not include an earlier paragraph of Justice Galligan's decision in her judgement, where he expressly denounces this very action:

While there were decisions in the past which have upheld discriminatory conditions in wills, in response to a query from the bench, counsel in this case were not prepared to argue that any court would today uphold a condition in a will which provides that a beneficiary is to be disinherited if he or she marries outside of a particular religious faith. I find compelling Mr. Eastman's argument that if a testator could not do so then his trustee could not do it for him. ${ }^{157}$

Further on, however, Justice Cronk provides a more nuanced reason for her hypothetical ruling that does not, at least facially, conflict with Justice Galligan's decision in Fox Estate. Towards the end of her reasoning on the hypothetical, she concluded that in light of her review of the case law, the doctrine of public policy was only applicable to conditional testamentary clauses that offer some form of entitlement. ${ }^{158}$ Unlike the scenario of a conditional, discriminatory clause as alluded to by Justice Galligan in Fox Estate, the hypothetical in Spence involved a testamentary clause that was unconditional and held no corresponding entitlement/disentitlement. In such circumstances, Justice Cronk reasoned that voiding such a clause would constitute "a material and unwarranted expansion of the doctrine of public policy in estates law". It would, she believed, unnecessarily comprise testamentary freedom given that voiding it would result in no change in the disposition of the estate. ${ }^{159}$ However, a simple examination of why public

154 Fox Estate, supra note 114 at para 20.

155 Supra note 151.

156 Ibid.

157 Fox Estate, supra note 114 at para 18.

158 Spence, supra note 6 at paras 84-85.

159 Ibid at para 85. 
policy has been applied to discrimination in the private law in Canada demonstrates why this ruling unnecessarily exposes Canadian society to a risk of harm contemplated in past decisions.

\section{The Importance of Public Policy's Applicability to Private Law in Canada's Multicultural Society}

As discussed above, in 1945 Justice Mackay found that discrimination within the private law, if left uncensored by courts of justice, would only serve to fragment and disable the functioning of multicultural societies like Canada. While that case was about restrictive covenants that forbade the sale of land to persons of certain ethnicities or religion, the principled reasoning of Mackay J. is equally applicable to other instances of discrimination within the private law. This article has detailed how this reasoning has been adopted by both the Ontario and New Brunswick Courts of Appeal in relation to testamentary trusts and private wills. It likewise argues that this principle is equally applicable to the hypothetical in Spence in at least two ways. First, while Justice Cronk's scenario involves a single act of discrimination between family members, due to the nature of estate law, courts could be perceived as condoning the use of the private law to perpetuate discrimination. Second, even if one does not accept this first argument, it is difficult to view the ratio of the hypothetical judgement and its immediate result as anything but judicially sanctioned discrimination. Once discrimination is condoned by courts of law, the potential for a broad and harmful impact on Canadian society is realized.

With respect to the first argument, most wills that contain gifts related to the contents of bank accounts or real property require validation by a court of probate. As Justice McInnes noted in Hurshman ${ }^{160}$ over 60 years ago, many wills require the assistance of courts in order to affect a testator's wishes. Other wills contain clauses or entire sections that require interpretation by a court of construction. Any judgement that validates a will containing discriminatory language could be perceived as a condonation of such discrimination by a court of law. ${ }^{161}$

In his concurring judgement in Spence, Lauwers J.A. observed that courts of probate neither condone nor approve particular bequests. ${ }^{162}$ Although Justice Lauwers was engaging with a different argument ${ }^{163}$ his point is taken. It is entirely plausible that a court, not asked to engage directly with a discriminatory clause in a will would attract no perceptions of endorsing the discrimination, simply because it granted the will probate.

However, while a court might not be perceived as sanctioning discrimination in the scenario above, the ratio and result of Spence attracts a very different perception. If a court expressly refuses to hear a public policy application with respect to explicit discrimination on the face of a will, a picture of judicially sanctioned discrimination readily emerges. According to Spence, this is exactly what courts, when faced with such applications, must do. By stating that such clauses can never be subject to a public policy application, no matter how discriminatory in nature they may be, intentionally or not, the Court of Appeal for Ontario has sanctioned the use of the private law as a tool of discrimination.

American legal scholar Patricia Williams has noted that the darkest moments of her nation's history have been marked not by a failure to correctly interpret the rights of an individual but the failure of its law makers and its courts to commit to their existence at all. ${ }^{164}$ Although Williams was writing about constitutional law, the role of public policy vis-a-vis discrimination in the private law is analogous given the role it has played in Canadian jurisprudence with respect to discrimination and the private law. Some

160 Supra note 64.

161 For a similar point in relation to testamentary gifts to "unworthy heirs" see Ziff, "Unworthy Heir”, supra note 129.

162 Spence, supra note 6 at para 129.

163 His point related to whether a court's action in probating a will evoked s 32 of the Charter; ibid at para 127.

164 Patricia J Williams, “Alchemical Notes: Reconstructing Ideals from Deconstructed Rights”, (1987) 22 Harv CR-CLL Rev 401 at 424. 
of the Canada's most notorious legal decisions concerning inequality perpetuated through the private law have been marked by refusals to engage with the doctrine or findings that public policy was inapplicable to the scenario. Indeed the last time the Supreme Court of Canada pronounced on the issue it held that racist discrimination was actually in keeping with public policy. ${ }^{165}$ The notion of a court turning a blind eye to something so blaringly inconsistent with the fundamental principles upon which its society has been built, is troubling in itself. The refusal of a court to address such a scenario when expressly asked to, however, sets a dangerous precedent of its own. Judicial permission to actively use the private law to perpetuate discrimination risks a constant repositioning of the baseline for bigotry within the private law. New normals can establish themselves quickly when tolerance for intolerance creeps into any institution charged with upholding and administering the rule of law.

In order for a testamentary clause to be discriminatory in a way that is offensive to public policy, it need not carry with it conditions and financial consequences for transgressing them. It is totally unnecessary to bar the complete application of public policy to an area of the private law based simply on the nature of a private law clause. Whether or not a particular public policy inquiry results in the voiding of an impugned testamentary or other type of private law provision is not the point. What remains fundamental to the argument that the private law should never be an unexamined and impenetrable shelter for discrimination, is the availability of some kind of mechanism to regulate discrimination in that area of the law. That is the role that has, in Canadian private law, been played by the doctrine of public policy. Removing all recourse to this tool effectively eliminates a court's ability to regulate certain instances of discrimination within the private law.

As we have seen from the charitable trust cases that followed Canada Trust Co., the application of public policy does not automatically translate into a finding that a certain clause contravenes it. It may be that most cruel statements included in a last will and testament will not amount to an offence of public policy. But certainly those akin to hate speech might. ${ }^{166}$ Further, although it is immaterial to the argument, voiding an offensive, unconditional clause may indeed impact the distribution of an estate. ${ }^{167}$ In any event, as history tells us, the very nature of the doctrine precludes, in the long run, its limitation from any distinct legal scenario.

\section{Precedent, Public Policy and the Lessons of History}

In support of both her rulings, Justice Cronk relied heavily on precedent. Midway through her decision, Cronk J.A. provided a list of public policy's past uses in relation to private wills. ${ }^{168}$ Unlike the

165 See Christie, supra note 58; Re Curran, [1939] OWN 191, 1939 CarswellOnt 167 (H Ct J) [Cited to Carswell]; Loew's Montréal Theatres Ltd c Reynolds, 1919 CarswellQue 61, 30 BR 459. Also see James W ST G Walker. “The Law's Confirmation of Racial Inferiority: Christie v York" in Barrington Walker, "The African Canadian Legal Odyssey: Historical Essays" (Toronto: University of Toronto Press, 2012) 243; and Constance Backhouse. "Bitterly Disappointed at the Spread of 'Colour Bar Tactics': Viola Desmond's Challenge to Racial Segregation, Nova Scotia, 1946" in Walker, ibid at 101.

166 See Grant J.'s discussion of this in McCorkill, supra note 17 at paras 50-53.

167 Notably, while the purpose of a court interfering with otherwise valid private law on the grounds of public policy is not to provide a personal remedy for an individual in some instances, voiding a discriminatory disinheritance clause may achieve just that. One example is if a will contained both a discriminatory clause that disinherits one child, and a class gift to the testator's "children". If the first clause is voided due to public policy, the otherwise disinherited child could be interpreted as able to take under the class gift with his or her siblings.

168 "The courts have recognized various categories of cases where public policy may be invoked to void a conditional testamentary gift. These include cases involving: i) conditions in restraint of marriage and those that interfere with marital relationships, e.g., conditional bequests that seek to induce celibacy or the separation of married couples; ii) conditions that interfere with the discharge of parental duties and undermine the parent-child relationship by 
testamentary clause in Spence, all of those mentioned in Justice Cronk's list were conditional in nature. They required a beneficiary or a trustee to act in a manner contrary to public policy in order for the testator's instructions to be carried out and/or for a beneficiary to take under the will. ${ }^{169}$ Justice Cronk did not accept that $M c$ Corkill represented an expansion of the doctrine to unconditional testamentary clauses, arguing that the New Brunswick case instead established a new kind of "unworthy heir", a beneficiary whose raison d'etre was contrary to public policy itself. ${ }^{170}$ She believed that the fact that the clause in McCorkill was also unconditional did not merit an enlargement of "the scope of the public policy doctrine in estate cases." 171

Although it is not the reason why Justice Cronk's hypothetical ruling is problematic, it is worth noting that similar arguments concerning the expansion of the doctrine have been made, some dating back over a century. All of them have inevitably failed in this goal.

In the 1851 decision of Egerton v. Brownlow, ${ }^{172}$ Baron Parke argued strongly against the application of the doctrine to novel scenarios in law. He acknowledged that while the doctrine had established itself within the common law for certain specific uses, the courts had no business creating "new heads" of it. ${ }^{173}$ While this view was adopted by some judges in subsequent decisions of the House of Lords, inevitably this proposition was downplayed or ignored within a decade by that same court. ${ }^{174}$ Nearly a hundred years later, in Re Millar Estate, ${ }^{175}$ the Chief Justice of Canada, while not expressly adopting Baron Parke's view, declared that the doctrine should only be applied in the clearest of cases, when the private law interest at issue threatened the safety, the economic or the social well-being of a state and "its people as a whole". ${ }^{176}$ Furthermore, the alleged harm had to be "substantially incontestable." 177 The restrictive spirit of this decision was described in Crockett J.'s concurring judgement as impossible to meet by any court, prompting him to wonder why the Supreme Court did not simply "renounce the rule entirely". ${ }^{178}$ However in the decades that followed Millar, the doctrine managed to survive and even expand in its application to private law issues. ${ }^{179}$ Notably, however, Duff C.J.'s test fared not nearly as well. ${ }^{180}$ Likewise, even Justice

disinheriting children if they live with a named parent; iii) conditions that disinherit a beneficiary if she takes steps to change her membership in a designated church or her other religious faith or affiliation; and iv) conditions that incite a beneficiary to commit a crime or to do any act prohibited by law." Spence, supra note 6 at para 55.

169 Ibid at para 56.

170 Ibid at para 63.

171 Ibid at para 58. Additionally, Justice Cronk's reasons imply her unease with the McCorkill decision in general, as they cite a critique of the case by Prof. Ziff, ibid at para 54.

172 Supra note 2. In this seminal case, the House of Lords held a virtual referendum on the doctrine's future, asking in addition to the five Law Lords hearing the appeal, the opinions of eleven additional judges concerning, among other things, the legitimacy of the doctrine. See also Winfield, supra note 29 at 88.

173 Supra note 2 at 123.

174 See Naylor, supra note 40; Rodriguez v Speyer Brothers, [1919] AC 59, [1918-19] All ER 884 (HL(Eng)); Fender v Mildmay, [1938] AC 1, [1937] 3 All ER 402 [Fender]. See also WSM Knight, "Public Policy in English Law" (1922) 38 LQ Rev 207 at 213.

175 [1938] SCR 1, 1937 CarswellOnt 108 [Millar]

176 Fender, supra note 174.

177 Millar, supra note 175 at para 15. It is not clear from Justice Duff's reasons if he meant for the test to apply to novel applications of the doctrine or all subsequent applications of the doctrine.

178 Ibid at para 30.

179 A Westlaw search reveals nearly 1000 decisions involving an application or consideration of the doctrine were reported since Re Millar.

180 Indeed, in Christie, supra note 58, decided only one year after Re Millar, the Supreme Court made no mention of the case or the Chief Justice's test at all. While Christie involved an application of public policy as codified by Quebec law, as discussed above the notion of good morals and public order in Quebec and public policy in the rest of Canada were equated with one another by the Supreme Court as early as the turn of the $20^{\text {th }}$ century; see supra note 113 and 
Tarnopolsky's "caution"181 in Canada Trust Co. that public policy should only be applied to instances of discrimination in quasi-public private law, has not been followed by Canadian courts.

Justice Cronk's attempt to limit the doctrine's past uses seems only to echo Baron Parke's attempt to do so over 150 years prior. Both efforts appear to base their limitation of the doctrine on an acceptance of established applications but draw the line at a further expansion. If nothing else, time proves these positions untenable with respect to the doctrine of public policy, a legal principle that is dependent upon and informed by the values of society. Best described as applicable "whenever the facts demanded it"182 the doctrine, applied on a case by case basis, has proven invulnerable to any categorical containment of its application to operations of private law.

As history shows us, a reliance on precedent concerning past uses of public policy is not a persuasive argument to support Justice Cronk's judgement in Spence. It also suggests that, in the long run, the Ontario Court of Appeal's decision in Spence may not prevent applications of the doctrine to any kind of testamentary clause if a court deems a public policy intervention necessary. However, the story may not be similar with respect to more immediate effects of the decision. Notably, in the most recent charitable trust decision of Royal Trust ${ }^{183}$, the terms of a scholarship were found to equate to those in Canada Trust $C o$. and were voided in accordance with public policy. However, the testator's will also contained a clause instructing that in the event that his scholarship's qualifications were "adjudged by a court of competent jurisdiction to be void for public policy" that the gift would be withdrawn entirely. ${ }^{184}$ Likely this instruction reflected the testator's wishes that the discriminatory conditions of his gift not be voided while the gift was preserved through the doctrine of cy-pres. However, this clause also indicates a general knowledge and acceptance by those practitioners in the field of wills and estate law that certain instances of discrimination are incompatible with current day Canadian public policy. The decision in Royal Trust was released two months before the Ontario Court of Appeal's decision in Spence. One cannot help but wonder what message Spence sends to this same field of professionals and their clients concerning public policy and discrimination in wills.

On June 9, 2016, the Supreme Court of Canada denied leave to appeal for both McCorkill and Spence ${ }^{185}$. As noted above, the last pronouncement concerning discrimination and public policy by the Supreme Court was that a Montreal tavern's policy to refuse service to black patrons was simply a business decision and not contrary to public policy. ${ }^{186}$ While presumably no court in Canada today would follow such precedent, the fact that decision has yet to be specifically renounced by the Supreme Court runs contrary to the basic values of Canada's constitutional democracy, its multicultural society and the rule of law.

accompanying text. Even within the discrimination and public policy cases reviewed in detail in this paper, Chief Justice Duff's test was referred to only four times and applied only in Canada Trust Co.(supra, note 75), where the motion judge found that the facts of the case did not meet the test's criteria, while Justice Tarnopolsky in his concurring OCA decision found that they did.

181 Canada Trust Co, supra note 75 at para 73.

182 Naylor, supra note 40.

183 Royal Trust, supra note 106.

184 Ibid at para 8.

185 Supra note 142.

186 Christie, supra note 58 at para 11. 


\section{CONCLUSION}

The Ontario Court of Appeal's 2016 decision in Spence was wrongly decided with respect to its limitation of public policy's application to discrimination in private wills. This is illustrated at least in part, by the history of the uniquely Canadian jurisprudence and the reasoning employed by courts in various provinces when applying the doctrine to instances of racism or religious intolerance. In areas of the law where the Charter and human rights codes do not apply, the doctrine has been used to regulate instances of discrimination ranging from discriminatory conditions in scholarships to an unconditional testamentary gift to a neo-nazi organization. In some of these instances, the doctrine has been employed in Canada to prevent the use of the private law to perpetuate discrimination offensive to Canada's public policy.

As noted above, at the core of public policy's role vis-a-vis discrimination in the private law lies the powerful argument that the private law must not become an unexamined and impenetrable shelter to protect discrimination. If left uncensored by systems of government and courts of law, discrimination can threaten the basic functioning of multicultural societies that depend on fundamental principles of equality and freedom. Canada is one of those societies. This was the reasoning behind the first application of the doctrine of public policy to discrimination in the private law by a common law court in 1945. It was also the reasoning adopted in subsequent decisions in this area of jurisprudence by the Ontario and New Brunswick Courts of Appeal.

However, in its latest decision concerning this issue, the Ontario Court of Appeal appears to have broken from this logic. It has instead issued a judgement that bars the application of public policy to a specific area of the private law. Given the role that the doctrine has played in combatting discrimination within the private law in Canada, the judgement provides a carte blanche for certain uses of one's will to perpetuate discrimination in the province of Ontario.

Some might argue that one family member discriminating against another in a private will is not what the Ontario Court of Appeal Justices in Canada Trust Co. had in mind when referencing the harm such discrimination could cause to Canada's multicultural society. However, this article has argued that these individual acts of discrimination, when unchecked by courts of law, and indeed when rendered immune from judicial scrutiny, result in the perception of judicially sanctioned discrimination. If a court issues a grant of probate for a will containing a discriminatory clause, this arguably could be perceived as a validation of not just the will but also the discrimination perpetuated by it. Secondly, and more importantly, it is difficult not to draw a conclusion of judicially condoned discrimination from a judgement that renders certain testamentary clauses immune to public policy scrutiny, the only private law mechanism that has been used to regulate discrimination in this area of the law in Canada.

Writing on this topic, Professor Bruce Ziff made the point that, "[i]t must be acknowledged that the law can do only so much to make the world a better place. Nevertheless, it should do as much as is feasible." 187 Traditionally, the doctrine of public policy has been applied to otherwise valid operations of the private law when the greater interest of the public good demanded it. In those instances where public law defenders of equality and freedom such as the Charter and human rights legislation do not apply, common law tools such as the doctrine of public policy must remain as an available check on discrimination. While history tells us that attempts like that of Spence to limit or constrain the doctrine have always ultimately failed, the short-term impact of this decision remains problematic, largely because of the message it sends. As it stands, in Ontario at least, testators have express permission to use their last wills and testaments as tools to perpetuate discrimination. While the Supreme Court of Canada refused

187 Ziff, “Unworthy Heir”, supra note 129. 
leave to appeal in Spence, there will continue to be cases concerning this issue in other provinces. ${ }^{188}$ Perhaps when this issue is next revisited, Canada's highest court will weigh in on the matter. The goal of the Supreme Court hearing such a case would not be to provide a concise formula for the doctrine's application in specific instances, if such a formula were even possible given the nature of the doctrine itself, but to acknowledge the doctrine's applicability to express uses of the private law to perpetuate discrimination. In doing so, it could not only correct its own dated precedent but could also take that opportunity to "expatiate the obvious", that no area of the law in Canada can or should be an unexamined and impenetrable shelter to protect discrimination.

188 Before the Ontario Court of Appeal's decision in Spence was released, an application to prove a will in solemn form was granted by the Saskatchewan Court of Queen's Bench in the case of Grams v Grams Estate. In that case the applicant contested a will on several grounds including public policy, alleging that the testator had excluded the applicant as a beneficiary from his will due to the applicant's sexual orientation. While the case ultimately settled out of court, the application judge, in deciding that the issue of public policy merited a trial, engaged in a review of the case law involving discrimination in private wills; 2015 SKQB 374, 261 ACWS (3d) 249, leave to appeal to CA refused, 2016 SKCA 12 at paras 20-23. 